\title{
Hematological values and total protein of Brasileiro de Hipismo and Breton mares during pregnancy
}

\author{
Valores hematológicos e proteína total de éguas Brasileiro de Hipismo e Bretão durante a gestação
}

\author{
César Andrey Galindo Orozco ${ }^{\mathrm{I}}$ Carla Braga Martins" Flora Helena de Freitas D’Angelis ${ }^{\mathrm{II}}$ \\ José Victor de Oliveira ${ }^{\mathrm{II}}$ José Corrêa de Lacerda-Neto ${ }^{\mathrm{IV}}$
}

RESUMO

Estudaram-se as variáveis eritrométricas, leucométricas e a concentração de proteína total (PT) de éguas gestantes das raças Brasileiro de Hipismo (BH) e Bretão. Utilizaram-se 175 éguas sadias, com 3 a 13 anos de idade. Dentre as éguas utilizadas, 89 foram da raça $B H$, divididas em 14 não-prenhes e 75 prenhes, e 86 éguas da raça Bretão divididas em 11 não-prenhes e 75 prenhes. As éguas foram subdivididas em quatro grupos por raça: grupo controle (éguas não-prenhes, $n=14$ para $B H$ e $n=11$ para Bretão); grupo I (primeiro período de gestação, 25-110 dias, $n=25$ para $B H$ e Bretão), grupo II (segundo período de gestação, 111-210 dias, $n=25$ para $B H e$ Bretão); e grupo III (terceiro período de gestação, 211-340 dias, $n=25$ para $B H$ e Bretão). Os valores médios de cada variável eritrométrica, leucométrica e de proteína total foram obtidos para cada raça e, posteriormente, realizou-se comparação entre as mesmas. O número de hemácias (He), volume globular (VG) e teor de hemoglobina $(\mathrm{Hb})$ aumentaram no segundo período de gestação e diminuíram no último período tanto para a raça $B H$, como para a raça Bretão. Além disso, essas mesmas variáveis apresentaram diferença estatística significativa tanto nas éguas não-prenhas como nas prenhes durante os três períodos gestacionais. Os valores médios obtidos de leucócitos e neutrófilos segmentados aumentaram a partir do segundo período de gestação para as duas raças estudadas.

Palavras-chave: éguas gestantes, hematologia, eqüinos, Bretão, Brasileiro de hipismo.

\section{ABSTRACT}

Erythrocyte and leukocyte parameters and total protein (TP) of Brasileiro de Hipismo (BH) and Breton mares were studied during pregnancy. A total of 175 healthy mares, varying from 3 to 13 years old were used. Among the animals,

\begin{abstract}
89 were BH mares (14 non pregnant and 75 pregnant) and 86 Breton mares (11 non pregnant and 75 pregnant). The mares were divided into four groups for each breed: control group (non pregnant mares). group 1 (first period of pregnancy, 25110 days, $n=25$ ), group 2 (second period of pregnancy, 111-210 days, $n=25$ ) and group 3 (third period of pregnancy, 211-340 days, $n=25$ ). The values for erythrocyte, leukocyte were compared with the obtained total protein. Red blood cells count (RBC), packed cell volume (PCV) and haemoglobin concentration $(\mathrm{Hb})$ increased in the second period of pregnancy and decreased in the last period in both the $\mathrm{BH}$ and Breton breed, furthermore these same variables were found to significantly higher in the $B H$ breed for non pregnant and pregnant mares during all three gestational periods. The numbers of total leucocytes and segmented neutrophils increased after the second period in both breeds studied.
\end{abstract}

Key words: pregnant mares, hematology, Breton, Brasileiro de Hipismo, equine.

\section{INTRODUCTION}

The proper management and rising of horses developed in Brazil, especially in the last years (RIBEIRO, 2003). Concomitantly, they have improved the care of the individuals, especially mares, since their health constitutes a basic factor for efficient breeding (CONCEIÇÃO et al., 2001).

Factors such as breed, sex, age, beaviour, handling, physiological changes and the period of the day, caninfluence the cellularconstituents and serumbiochemistry of the blood (TAYLOR-MACALLISTER et al., 1997).

\footnotetext{
'Programa de Pós-graduação em Medicina veterinária, Faculdade de Ciências Agrárias e Veterinárias (FCAV), Universidade Estadual Paulista (UNESP), Jaboticabal, SP, Brasil. Univerdidad de La Salle, Bogotá, Colômbia.

IIPrograma de Pós-graduação em Medicina Veterinária, FCAV/UNESP, Jaboticabal, SP, Brasil.

IIIHaras Pólo Regional de Desenvolvimento Tecnológico de Agronegócios da Alta, Mogiana, Colina, São Paulo, Brasil.

${ }^{\text {IV }}$ Departamento de Clínica e Cirurgia Veterinária, FCAV/UNESP. Via de Acesso Prof. Paulo Donato Castellane, s/n, 14884-900, Jaboticabal, SP, Brasil. E-mail: jlacerda@fcav.unesp.br. Autor para correspondência.
} 
Therefore, many studies have been conducted aiming at establishing hematological standards for horses of different breeds, ages and physiological stages in different continents around world (NORONHA et al., 2000; VAZ et al., 2000).

The increased demand for sport horses has led to development a specialized national breed in called Brasileiro de Hipismo ( $\mathrm{BH})$, these animals are characterized by having an energetic, docile and vivacious temperament, in addition to a physical size that varies from medium to large, allowing for "real equine” performance (LASSEN \& SWARDSON, 1995). On the other hand, the Breton horse is used in some countries for light and/or weighted traction, as well as a milker, because of its good milk production (MESSER, 1995; SWENSON, 1996).

The physiological changes in the mare during pregnancy make it larger with a higher body demand for its maintenance and thereby also resulting in alterations in blood homeostasis (MORRIS, 1998). Therefore, the magnitude of variations in hematological parameters in pregnant mares can be very useful in physicpathological tools related to the accompaniment and handling of female horses (KRAMER, 2000).

The lack of scientific studies referring to hematological parameters and total plasma protein concentration in horses, specifically in pregnant mares, makes it difficult for the clinical veterinarian to perform blood examinations, especially physiological changes that may occur during the different periods of pregnancy (STELL \& WHITLOCK, 1960; TAYLORMACALLISTER et al., 1997)

Therefore, this study was aimed at examining erythrocyte and leukocyte parameters, total protein concentration in healthy females of the breeds Brasileiro de Hipismo and Breton, during the first, second and third period of pregnancy. Mean values obtained for each hematological variable and total protein during the different periods of pregnancy were compared for each breed and between breeds to establish reference values for the $\mathrm{BH}$ and Breton breeds during gestation, under specific handling conditions and grazing in a tropical climate.

\section{MATERIAL AND METHODS}

A total of 175 healthy mares of the Brasileiro de Hipismo and Breton breeds, ranging between 3 to 13 years of age, from the Haras Pólo Regional de Desenvolvimento Tecnológico de Agronegócios da Alta Mogiana in Colina, SP-Brazil, and kept under similar feeding and management conditions, formed the material for the present study. The animals were maintained in an extensive system on grazing areas of Capim Colonião (Panicum maximum Jacq. var. maximum). Tanzania (Panicum maximum to var. Tanzânia), with daily supplementation of grain, mineralized salt and water ad libitum. Among the mares studied, 89 were of the $\mathrm{BH}$ breed (14 non pregnant +75 pregnant) and 86 were of the Breton breed (11 non pregnant +75 pregnant). All mares were clinically healthy, and they were handled carefully to reduce any possible effects of stress on the parameters analyzed.

The animals of the two breeds, Brasileiro de Hipismo and Breton, were distributed in accordance with the different physiological conditions and whether or not pregnant, into four different groups for the three gestation periods and a control. The first period was considered to be 25-110 days of gestation, the second 111-210 days and the third 211-340 days. The BH groups included a control group of non pregnant mares $(n=14)$ to which just one sample were collected during the experiment, group 1 for mares in the first period $(n=25)$; group 2 for mares in the second period $(n=25)$ and group 3 for mares in the third period ( $n=25)$. The Breton groups included a control group of non pregnant mares $(n=11)$ to which just one sample were collected during the experiment, group 1 for mares in the first period $(n=25)$, group 2 for mares in the second period $(n=25)$ and group 3 for mares in the third period $(n=25)$.

For each sample, $5 \mathrm{~mL}$ of blood were collected from each animal the jugular vein and transferred to assay tubes containing 10\% EDTA. Red blood cells count (RBC), haemoglobin concentration (Hb) and packed cell volume (PCV) were determined. The hematological indices mean corpuscular volume (MCV), mean corpuscular haemoglobin (MCH) and mean corpuscular haemoglobin concentration (MCHC) were calculated. Total white blood cell count (WBC) and differential leukocyte counts were performed and total protein (TP) concentration was determined.

The Coulter counter (CELM CC 510 Industria Brasileira) were used to determine $\mathrm{RBC}$ and WBC, PCV was determined by the microhematocrit method and $\mathrm{Hb}$ by the spectophotometric method for cyanmethaemoglobin with readings at $540 \mathrm{~nm}$. MCV, $\mathrm{MCH}$ and MCHC were indirectly calculated automatically. Plasma obtained by centrifugation of blood collected was used to determinate total plasma protein concentration using a refractometry method (ATAGO T2-NE). Blood smears were stained by the method of Rosenfeld for differential leukocyte count.

The data was submitted to statistical analysis using the computational program SAS (Statistical 
Analysis System). Analysis of variance (ANOVA). It was analyzed according to a completely randomized $2 \mathrm{x}$ 4 experimental design. Comparisons of the values obtained for the different parameters studied in the experimental groups were made using Tukey's test at the $5 \%$ level of significance $(\mathrm{P} \leq 05)$.

\section{RESULTS AND DISCUSSION}

In $\mathrm{BH}$ mares, there was an increase in erythrocyte count at the second period, differing statistically from the control group and the other gestation periods (Table 1). An elevation in PCV appeared in the second gestation period, which was significantly different only compared to the third period. $\mathrm{Hb}$ concentration was also increased in the second period and differed significantly from the third period. MCV was higher in third period, differing significantly from the control group and the second gestation period. In the second period, MCV was significantly lower than the other periods. $\mathrm{MCH}$ was diminished during second gestation period. Being significantly different from the control group and the other pregnant groups.

In Breton mares, the RBC was significantly lower in third period relating to levels at other gestation periods (Table 1). There was a reduction in globular volume during the first period, followed by a significant increase in second gestation period. These elevated levels stabilized in third period and were similar to those seen in the control group. MCV showed a significant difference in the first period in relation to the third, where it was higher instead to be latter. MCHC was significantly higher during the first period than in the third.

Significant differences were found between the two breeds studied with RBC (Table 1). MCV showed significant difference between the breeds in the first and second period of gestation. MCHC and $\mathrm{MCH}$ were significantly higher in the Breton breed during first and second period respectively.

The leucogram for $\mathrm{BH}$ is shown in table 2. There was a statistically significant reduction in total leukocytes during the second period, unlike in the third gestation period when a significant increase occurred. Segmented neutrophils were significantly increased in third period in relation to the other groups. Eosinophils were significantly higher in the control group than in the different gestation groups. There was no significant difference for band neutrophils, lymphocytes, basophils and monocytes among the different groups studied.

In the Breton mares (Table 2), the WBC different gestation periods increased gradually during pregnancy, showing a significant difference comparing the first group with the others groups studied. The mean number of segmented neutrophils increased in the last period of gestation, being significantly higher when compared with previous periods and control mares. A statistical difference was observed in the mean number of band neutrophils between the second and third period of gestation. The eosinophils level was significantly lower when checked in first period groups related to

Table 1 - Values for red blood cell count (RBC), packed cell volume (PCV), haemoglobin (Hb), mean corpuscular volume (MCV), mean corpuscular haemoglobin (MCH), mean corpuscular haemoglobin concentration (MCHC) and total plasma protein (TP) for mares of the Brasileiro de Hipismo (BH) and Breton during pregnancy.

\begin{tabular}{|c|c|c|c|c|c|}
\hline Parameter & Breed & Control group ${ }^{*}$ & Group $1^{*}$ & Group $2^{*}$ & Group $3^{*}$ \\
\hline \multirow[t]{2}{*}{$\mathrm{RBC}\left(\mathrm{x} 10^{6} / \mu \mathrm{L}\right)$} & $\mathrm{BH}$ & $7.78 \pm 0.21^{\mathrm{B}, \mathrm{a}}$ & $7.65 \pm 0.16^{\mathrm{B}, \mathrm{a}}$ & $9.57 \pm 0.16^{\mathrm{A}, \mathrm{a}}$ & $6.97 \pm 0.16^{\mathrm{B}, \mathrm{a}}$ \\
\hline & Breton & $6.31 \pm 0.24^{\mathrm{AB}, \mathrm{b}}$ & $6.29 \pm 0.16^{\mathrm{AB}, \mathrm{b}}$ & $6.93 \pm 0.16^{\mathrm{A}, \mathrm{b}}$ & $6.17 \pm 0.16^{\mathrm{B}, \mathrm{b}}$ \\
\hline \multirow[t]{2}{*}{ PCV (\%) } & $\mathrm{BH}$ & $36.71 \pm 0.88^{\mathrm{AB}, \mathrm{a}}$ & $37.20 \pm 0.65^{\mathrm{AB}, \mathrm{a}}$ & $39.80 \pm 0.65^{\mathrm{A}, \mathrm{a}}$ & $35.88 \pm 0.65^{\mathrm{B}, \mathrm{a}}$ \\
\hline & Breton & $30.18 \pm 0.99^{\mathrm{AB}, \mathrm{b}}$ & $28.04 \pm 0.65^{\mathrm{B}, \mathrm{b}}$ & $32.48 \pm 0.65^{\mathrm{A}, \mathrm{b}}$ & $30.68 \pm 0.65^{\mathrm{B}, \mathrm{b}}$ \\
\hline \multirow[t]{2}{*}{$\mathrm{Hb}(\mathrm{g} / \mathrm{dL})$} & $\mathrm{BH}$ & $13.30 \pm 0.32^{\mathrm{AB}, \mathrm{a}}$ & $12.76 \pm 0.24^{\mathrm{AB}, \mathrm{a}}$ & $13.48 \pm 0.24^{\mathrm{A}, \mathrm{a}}$ & $12.15 \pm 0.24^{\mathrm{B}, \mathrm{a}}$ \\
\hline & Breton & $10.50 \pm 0.36^{\mathrm{A}, \mathrm{b}}$ & $10.34 \pm 0.24^{\mathrm{A}, \mathrm{b}}$ & $11.32 \pm 0.24^{\mathrm{A}, \mathrm{b}}$ & $10.56 \pm 0.24^{\mathrm{A}, \mathrm{b}}$ \\
\hline \multirow[t]{2}{*}{ MCV (fL) } & $\mathrm{BH}$ & $47.24 \pm 0.88^{\mathrm{B}, \mathrm{a}}$ & $48.67 \pm 0.66^{\mathrm{AB}, \mathrm{a}}$ & $42.01 \pm 0.66^{\mathrm{C}, \mathrm{b}}$ & $51.47 \pm 0.66^{\mathrm{A}, \mathrm{a}}$ \\
\hline & Breton & $47.85 \pm 1.00^{\mathrm{AB}, \mathrm{a}}$ & $44.72 \pm 0.66^{\mathrm{B}, \mathrm{b}}$ & $46.93 \pm 0.66^{\mathrm{AB}, \mathrm{a}}$ & $49.80 \pm 0.66^{\mathrm{A}, \mathrm{a}}$ \\
\hline \multirow[t]{2}{*}{ MCH (pg) } & $\mathrm{BH}$ & $17.11 \pm 0.42^{\mathrm{A}, \mathrm{a}}$ & $16.74 \pm 0.31^{\mathrm{A}, \mathrm{a}}$ & $14.22 \pm 0.31^{\mathrm{B}, \mathrm{b}}$ & $17.50 \pm 0.31^{\mathrm{A}, \mathrm{a}}$ \\
\hline & Breton & $16.77 \pm 0.47^{\mathrm{A}, \mathrm{a}}$ & $16.48 \pm 0.31^{\mathrm{A}, \mathrm{a}}$ & $16.37 \pm 0.31^{\mathrm{A}, \mathrm{a}}$ & $17.15 \pm 0.31^{\mathrm{A}, \mathrm{a}}$ \\
\hline \multirow[t]{2}{*}{ MCHC (\%) } & $\mathrm{BH}$ & $36.23 \pm 0.61^{\mathrm{A}, \mathrm{a}}$ & $34.41 \pm 0.46^{\mathrm{A}, \mathrm{b}}$ & $33.88 \pm 0.46^{\mathrm{A}, \mathrm{a}}$ & $33.98 \pm 0.46^{\mathrm{A}, \mathrm{a}}$ \\
\hline & Breton & $34.93 \pm 0.69^{\mathrm{AB}, \mathrm{a}}$ & $36.85 \pm 0.46^{\mathrm{A}, \mathrm{a}}$ & $34.91 \pm 0.46^{\mathrm{AB}, \mathrm{a}}$ & $34.46 \pm 0.46^{\mathrm{B}, \mathrm{a}}$ \\
\hline \multirow[t]{2}{*}{ TP (g/dL) } & $\mathrm{BH}$ & $7.87 \pm 0.14^{\mathrm{A}, \mathrm{a}}$ & $7.65 \pm 0.10^{\mathrm{A}, \mathrm{a}}$ & $7.53 \pm 0.10^{\mathrm{A}, \mathrm{a}}$ & $7.59 \pm 0.10^{\mathrm{A}, \mathrm{a}}$ \\
\hline & Breton & $7.85 \pm 0.15^{\mathrm{A}, \mathrm{a}}$ & $7.66 \pm 0.10^{\mathrm{A}, \mathrm{a}}$ & $7.94 \pm 0.10^{\mathrm{A}, \mathrm{a}}$ & $7.88 \pm 0.10^{\mathrm{A}, \mathrm{a}}$ \\
\hline
\end{tabular}

${ }^{*}$ Control group (non pregnant mares); ${ }^{*}$ Group 1: First period (25 -110 days of gestation); *Group 2: Second period (111 -210 days of gestation); ${ }^{*}$ Group 3: Third period (211 -340 days of gestation). Different capital letters indicate statistically significant values (P<.05) in the same line for each variable. Different small letters indicate statistically significant values $(\mathrm{P}<.05)$ in the same column for each variable. 
Table 2 - Values for total white blood cell count (WBC) and numbers of segmented neutrophils (Seg.Neu), band neutrophils (Band. Neu), lymphocytes (Lym), eosinophils (Eos), basophils (Bas) and monocytes (Mon) for mares Brasileiro de Hipismo (BH) and Breton during pregnancy.

\begin{tabular}{|c|c|c|c|c|c|}
\hline $\begin{array}{l}\text { Parameter } \\
\left(\mathrm{x} 10^{3} / \mu \mathrm{L}\right)\end{array}$ & Breed & Control group ${ }^{*}$ & Group $1^{*}$ & Group $2^{*}$ & Group $3^{*}$ \\
\hline \multirow{2}{*}{ WBC } & $\mathrm{BH}$ & $7.87 \pm 0.32^{\mathrm{AB}, \mathrm{a}}$ & $7.55 \pm 0.24^{\mathrm{AB}, \mathrm{a}}$ & $7.28 \pm 0.24^{\mathrm{B}, \mathrm{a}}$ & $8.38 \pm 0.24^{\mathrm{A}, \mathrm{a}}$ \\
\hline & Breton & $7.01 \pm 0.36^{\mathrm{B}, \mathrm{a}}$ & $6.51 \pm 0.24^{\mathrm{C}, \mathrm{b}}$ & $7.52 \pm 0.24^{\mathrm{B}, \mathrm{a}}$ & $8.85 \pm 0.24^{\mathrm{A}, \mathrm{a}}$ \\
\hline \multirow{2}{*}{ Seg. Neu } & $\mathrm{BH}$ & $3.47 \pm 0.28^{\mathrm{B}, \mathrm{a}}$ & $3.75 \pm 0.21^{\mathrm{B}, \mathrm{a}}$ & $3.61 \pm 0.21^{\mathrm{B}, \mathrm{a}}$ & $4.85 \pm 0.21^{\mathrm{A}, \mathrm{a}}$ \\
\hline & Breton & $3.62 \pm 0.32^{\mathrm{B}, \mathrm{a}}$ & $3.34 \pm 0.21^{\mathrm{B}, \mathrm{a}}$ & $3.73 \pm 0.21^{\mathrm{B}, \mathrm{a}}$ & $5.57 \pm 0.21^{\mathrm{A}, \mathrm{a}}$ \\
\hline \multirow{2}{*}{ Band. Neu } & $\mathrm{BH}$ & $0.02 \pm 0.01^{\mathrm{A}, \mathrm{a}}$ & $0.01 \pm 0.008^{\mathrm{A}, \mathrm{a}}$ & $0.02 \pm 0.008^{\mathrm{A}, \mathrm{a}}$ & $0.01 \pm 0.008^{\mathrm{A}, \mathrm{b}}$ \\
\hline & Breton & $0.03 \pm 0.01^{\mathrm{AB}, \mathrm{a}}$ & $0.01 \pm 0.008^{\mathrm{AB}, \mathrm{a}}$ & $0.01 \pm 0.008^{\mathrm{B}, \mathrm{a}}$ & $0.05 \pm 0.008^{\mathrm{A}, \mathrm{a}}$ \\
\hline \multirow{2}{*}{ Lym } & $\mathrm{BH}$ & $3.83 \pm 0.23^{\mathrm{A}, \mathrm{a}}$ & $3.36 \pm 0.17^{\mathrm{A}, \mathrm{a}}$ & $3.14 \pm 0.17^{\mathrm{A}, \mathrm{a}}$ & $3.14 \pm 0.17^{\mathrm{A}, \mathrm{a}}$ \\
\hline & Breton & $2.84 \pm 0.26^{\mathrm{A}, \mathrm{a}}$ & $2.78 \pm 0.17^{\mathrm{A}, \mathrm{a}}$ & $3.26 \pm 0.17^{\mathrm{A}, \mathrm{a}}$ & $2.64 \pm 0.17^{\mathrm{A}, \mathrm{a}}$ \\
\hline \multirow{2}{*}{ Eos } & $\mathrm{BH}$ & $0.310 \pm 0.04^{\mathrm{A}, \mathrm{a}}$ & $0.213 \pm 0.03^{\mathrm{B}, \mathrm{a}}$ & $0.212 \pm 0.03^{\mathrm{B}, \mathrm{a}}$ & $0.196 \pm 0.03^{\mathrm{B}, \mathrm{b}}$ \\
\hline & Breton & $0.197 \pm 0.04^{\mathrm{A}, \mathrm{b}}$ & $0.196 \pm 0.03^{\mathrm{A}, \mathrm{a}}$ & $0.280 \pm 0.03^{\mathrm{B}, \mathrm{a}}$ & $0.322 \pm 0.03^{\mathrm{B}, \mathrm{a}}$ \\
\hline \multirow{2}{*}{ Bas } & $\mathrm{BH}$ & $0.100 \pm 0.02^{\mathrm{A}, \mathrm{a}}$ & $0.044 \pm 0.01^{\mathrm{A}, \mathrm{a}}$ & $0.100 \pm 0.01^{\mathrm{A}, \mathrm{a}}$ & $0.064 \pm 0.01^{\mathrm{A}, \mathrm{b}}$ \\
\hline & Breton & $0.148 \pm 0.02^{\mathrm{A}, \mathrm{a}}$ & $0.047 \pm 0.01^{\mathrm{B}, \mathrm{a}}$ & $0.107 \pm 0.01^{\mathrm{AB}, \mathrm{a}}$ & $0.153 \pm 0.01^{\mathrm{A}, \mathrm{a}}$ \\
\hline \multirow{2}{*}{ Mon } & $\mathrm{BH}$ & $0.089 \pm 0.03^{\mathrm{A}, \mathrm{a}}$ & $0.157 \pm 0.02^{\mathrm{A}, \mathrm{a}}$ & $0.189 \pm 0.02^{\mathrm{A}, \mathrm{a}}$ & $0.128 \pm 0.02^{\mathrm{A}, \mathrm{a}}$ \\
\hline & Breton & $0.171 \pm 0.03^{\mathrm{A}, \mathrm{a}}$ & $0.124 \pm 0.02^{\mathrm{A}, \mathrm{a}}$ & $0.129 \pm 0.02^{\mathrm{A}, \mathrm{a}}$ & $0.142 \pm 0.02^{\mathrm{A}, \mathrm{a}}$ \\
\hline
\end{tabular}

${ }^{*}$ Control group (non pregnant mares); * Group 1: First period (25 -110 days of gestation). *Group 2: Second period (111 - 210 days of gestation); *Group 3: Third period (211 -340 days gestation). Different capital letters indicate statistically significant values $(\mathrm{P}<.05)$ in the same line for each variable. Different small letters indicate statistically significant values $(\mathrm{P}<.05)$ in the same column for each variable.

second and third gestation periods. The basophils count was significantly lower during the first period compared to the control and third period. There was no significant difference in the mean number of lymphocytes or monocytes among the different groups studied for the Breton breed.

During the first period, the total leukocyte was significantly different between the two breeds, where the BH breed had higher levels. In the third period, there was a significant difference in the mean number of band neutrophils between the two breeds (Table 2), being higher in the Breton mares. Eosinophils differed significantly between the two breeds, where it was higher in the $\mathrm{BH}$ breed for the group control and higher in the Breton breed during the third period of gestation. Basophils were significantly higher in the Breton mares during the third period. Segmented neutrophils, lymphocytes and monocytes did not show any significant difference between the two breeds during gestation.

Regarding to the origin of the two breeds studied, horses are part of the development of the $\mathrm{BH}$ breed as well mostly descendents of Arabian breed horses which are considered hot-blooded (KANEKO, 1997). These animals are characterized by their higher metabolic requirements, and consequently have higher levels of RBC, PCV and Hb, compared to horses of the Breton breed, according to findings reported by (MESSER, 1995; LASSEN \& SWARDSON, 1995;
MORRIS, 1998). Physiologically, higher RBC, hematocrit and haemoglobin levels can play a role in better physical condition, such as in sports activities (VAZ et al., 2000).

A typical example of this relationship is observed in Thoroughbred horses, which possess higher levels of these variables, which make them well suited for sport activities that require maximum metabolic nutrient utilization (JULIAN, 1956; SWENSON, 1996).

The Breton breed belongs to the group of cold-blooded horses, which are not of Arabian ancestral origin. These horses are characterized by a docile temperament, having a lower metabolic rate. Therefore, these horses have lower RBC hematocrit and haemoglobin levels in relation to horses of hot temperament observed by KRAMER (2000), which agree with the findings of this study.

Factors such as breed and physiological changes during the pregnancy influenced the results in this study in accordance with TAYLOR-MACALLISTER et al. (1997). Nevertheless, factors such sex and age did not generate differences in the studied variables agreeing with VAZ et al. (2000).

In both breeds studied, there was a significant rise in RBC, hematocrit and haemoglobin in the second period. However, these values diminished in the two breeds during the final period of pregnancy. According to SOUZA et al. (2002), fetal growth that occurs in that period of pregnancy produces a greater oxygen demand. This greater need for oxygen is 
compensated by the endocrine system that stimulates the release of erythropoietin by the renal tissue (PLASCHKA et al., 1997). The secretion of this circulating glycoprotein stimulates increased production of erythrocytes in the bone marrow (LURIE, 1993). This phenomenon, which has been described in pregnant rabbits (KIM, 2002) and pregnant women (SOUZA et al., 2002), has also been observed by VAZ et al. (2000) in Arabian pregnant mares.

According to SOUZA et al. (2002), there is $40-50 \%$ an increase in blood's volume for pregnant women. This means an increase in plasma volume as well the total number of erythrocytes and leukocytes in the blood circulation, which are produced by physiological adjustments in the endocrine and renal systems. It is believed that this expansion in plasma volume is necessary to supply the increasing demands of uterine blood volume, where the standard level increases in pregnancy. The reduction in RBC, hematocrit and haemoglobin, occurs in the third period of gestation, which represents the main cause of "pregnant physiological anemia” a clinical condition described in various species (KIM, 2002; SOUZA et al., 2002). This phenomenon was observed in this study, in which these hematological variables decreased during the last gestation period in both breeds studied.

Another possible physiological cause of the decline in $\mathrm{Hb}$ is the reduced average lifespan of circulating erythrocytes in pregnant females compared to non-pregnant ones (LURIE, 1993). According to the author, this condition leads to a hematopoietic emergency, promoting an increase in erythropoietin concentration and erythrocytes.

The results found for MCV and RBC suggest an increase in the number of immature erythrocytes, which would be in accordance with findings in pregnant rats, rabbits and women reported by (KIM, 2002; LURIE, 1993).

The MCH increased in the two breeds during the third pregnant period. Similar to studies by MORRIS (1998), who attributed these findings to the possible presence of immature erythrocytes in the peripheral blood.

MCHC was higher in the first period in the Breton breed, evidenced by a significant difference between the breeds. However, this parameter was not relevant and happened within the established values for horses according to (MESSER, 1995; PLASCHKA et al., 1997; KRAMER, 2000).

The total white blood cell count, the values obtained in the first period differed between the two breeds studied, being lower in the Breton breed although this difference was significant, these values were within normal levels for horses (GRAHAM-THIERS et al., 2000; KANEKO, 1997). These results demonstrate the extensive range between the upper and lower normal limits of this variable, since lower values were recorded by CONCEIÇÃO et al. (2001).

In the advanced stage of gestation, there is an endogenous adrenaline release which induces the greater mobilization of neutrophils in the circulation resulting in an increase in total leucocyte count (KRAMER, 2000). During the last period of gestation the number of leucocytes increased gradually being higher than the ones described by VAZ et al. (2000) in Arabian pregnant mares.

Band neutrophils showed a significant difference between the breeds in the last period of pregnancy, being notably higher in the Breton breed. However, these values were between the intervals described for horses by (KANEKO et al., 1997; PLASCHKA et al., 1997).

The values found for lymphocytes were not different between the breeds studied, and within the normal range of horses according to TAYLORMACALLISTER et al. (1997) and MORRIS (1998). However these numbers were lower than that obtained in Arabian pregnant mares (VAZ et al., 2000) which were closer to those found in Thoroughbreds (FELDMAN et al., 2000).

The number of eosinophils in the $\mathrm{BH}$ breed was elevated in the control group and declined gradually until the end of pregnancy. The converse has been seen in the Breton mares, where the control group had lower numbers, which increased gradually with advancing pregnancy. Considering that the eosinophil reflects an immunological response of the organism to parasitic or allergic processes (KANEKO, 1997), it is proposed that in this case the higher number of eosinophils in Breton mares indicates a greater resistance to parasitic loads to which these animals are subjected at the end of gestation (NORONHA et al., 2000). Similar ranges of eosinophils have been observed in Arabian pregnant mares(VAZ et al., 2000).

There was a significant difference in basophil count between the breeds in the third period of pregnancy, however the values obtained within the reference intervals reported by other investigators (CONCEIÇÃO et al., 2001; RIBEIRO, 2003). For the monocytes there was no significant difference between the breeds during gestation. and the numbers observed agree with those reported by MESSER (1995) and LASSEN \& SWARDSON (1995). 


\section{CONCLUSION}

It was demonstrated in this study that the mean values of the different red blood cell count and white blood cell parameters showed significant changes during gestation. RBC, PCV and Hb increased in both breeds in the second period. The $\mathrm{BH}$ mares showed higher RBC, PCV and $\mathrm{Hb}$ than the Breton breed, while total WBC and segmented neutrophils increased after the second gestation period in both breeds studied, furthermore, the total protein concentration was not altered significantly in any of the studied breeds during the gestation.

Data in this study are the first hematological reference of the pregnancy mares in Brasileiro de Hipismo and Breton breeds; this will allow veterinarians to establish an appropriate a interpretation of laboratory data, and these results obtained can be used as for reference values in the clinical evaluation of pregnant mares of the $\mathrm{BH}$ and Breton breeds.

\section{REFERENCES}

CONCEIÇÃO, M. et al. Hemograma e bioquímica sérica de eqüinos da raça Quarto-de-Milha antes e após exercício. Veterinária Notícias, v.14, n.2, p.87-92, 2001.

FELDMAN, B.F. et al. Schalm's veterinary hematology. Philadelphia: Williams \& Wilkins, 2000. 1344p.

GRAHAM-THIERS, P.M et al. Protein status of exercising Arabian horses fed diets containing $14 \%$ or $7.5 \%$ crude protein fortified with lysine and threonine. Journal Equine Veterinary Science, v.20, n.8, p.516-521, 2000.

JULIAN, L.M. et al. Blood volume body water. and body fat of the horse. Journal of Applied Physiology, v.8. p.651-653, 1956.

KANEKO, J.J. et al. Clinical biochemistry of domestic animals. San Diego: Academic,1997. 932p.

KIM, J.C. Haematological changes during normal pregnancy in New Zealand white rabbits: a longitudinal study. Comparative Clinical Pathology, v.11, p.98-106, 2002.

KRAMER, J.W. Normal hematology of the horse. In: FELDMAN, B.F. et al. Schalm's veterinary hematology. Philadelphia: Williams \& Wilkins, 2000. Cap.165, p.10691074.
LASSEN, E.D.; SWARDSON, C.J. Hematology and hemostasis in the horses: normal functions and common abnormalities. Veterinary Clinics of North America: Equine Practice, v.11, n.3, p.341-389, 1995.

LURIE S. Changes in age distribution of erythrocytes during pregnancy: a longitudinal study. Gynecologic and Obstetric Investigation, v.36, n.3, p.141-144, 1993.

MESSER, N.T. The use of laboratory tests in equine practice. Veterinary Clinics of North America: Equine Practice, v.11, n.31, p.345-350, 1995.

MORRIS D.D. Enfermedades del sistema hemolinfático. In: COLAHAN, P.T.; MAYHEW, I.G. Medicina y cirugia equina. 4.ed. Buenos Aires: Inter-Médica, 1998. V.2, cap.16, p.16191678 .

NORONHA T.A. et al. Influência de fatores etários e sexuais no eritrograma de eqüinos clinicamente sadios. da raça Mangalarga. Revista Brasileira de Medicina Veterinária, v.22, n.2, p.8588, 2000.

PLASCHKA, S.G. et al. Parámetros hematológicos y bioquímicos en el parto de la yegua de raza española. Medicina Veterinaria, v.14, n.4, p.205-209, 1997.

RIBEIRO, C.A. Hemograma e valores de constituintes séricos de eqüinos sadios da raça pantaneira. 2003. 50f. Dissertação (Mestrado em Medicina Veterinária na área de Clínica Medica) - Faculdade de Ciências Agrárias e Veterinárias, Universidade Estadual Paulista, Jaboticabal.

SOUZA, A.I. et al. Alterações hematológicas e gravidez. Revista Brasileira de Hematologia e Hemoterapia, v.24, n.1, p.2936, 2002.

STEEL, J.D.; WHITLOCK, L.E. Observations on the haematology of thoroughbred and standard-bred horses in training and racing. Australian Veterinary Journal, v.1, p.136-142, 1960 .

SWENSON, M.J. Propriedades fisiológicas e constituintes químicos e celulares do sangue. In: DUKES, H.H. Fisiologia dos animais domésticos. 11.ed. Rio de Janeiro, 1996. Cap.3, p.19-43.

TAYLOR-MACALLISTER, C. et al. Haematology and serum biochemistry evaluation in normal postpartum mares. Equine Veterinary Journal, v.29, n.3, p.234-235. 1997.

VAZ, B.B.D. et al. Constituintes hematimétricos do sangue de éguas gestantes de raça Árabe. Veterinária Noticias, v.6, n.1, p.51-55, 2000. 